\title{
PENINGKATAN KEAKTIFAN BERTANYA MELALUI INKUIRI TERBIMBING SISWA KELAS X MIA 6 SMA NEGERI 1 KARANGANYAR TAHUN PELAJARAN 2015/2016
}

\author{
WAHYU KUSUMAWARDANI, MARIDI , MUZAYYINAH \\ Program Studi Pendidikan Biologi \\ Fakultas Keguruan dan Ilmu Pendidikan \\ Universitas Sebelas Maret \\ Jl. Ir. Sutami 36 A, Surakarta, 57126, Indonesia \\ *Corresponding Author: ayu wardanni@yahoo.com
}

Manuscript received : 14 Juni 2016 Revision accepted: 15 Agustus 2016

\begin{abstract}
The research aims to apply the guided inquiry model to improve questioning activity in the learning material "Animalia" in class $\mathrm{X}$ Science 6 of SMA Negeri 1 Karanganyar in 2015/2016 academic year. The research was a classroom action research which was done in three cycles covering planning, action, observation, and reflection stage. The learning model applied was guided inquiry model including six stages, they are: observe, formulate inquiry question, develop hypothesis, design and conduct investigation, analyze data, and arguing. Subject of the research was 40 students of X Science 6 of SMA Negeri 1 Karanganyar in 2015/2016 academic year. The data of the research was gained by doing observation, interview, and documentation. The writer analyzed the data using descriptive qualitative analyzing technique. The result shows that applying guided inquiry model improve the score of questioning activity in the learning material "Animalia" of X Science 6 students of SMA Negeri 1 Karanganyar in 2015/2016 academic year. The improvement of students' questioning activity is showed from the improving score of students' questioning activity score to teacher, to students, and in wrtitten from pre cycle stage until cycle 3 . The score of questioning activity from students to teacher improves from $7,5 \%$ or 3 students in pre cycle to $40 \%$ or 16 students in cycle $1,50 \%$ or 20 students in cycle 2 and $55 \%$ or 22 student in cycle 3 . The score of questioning activity from students to student improves from $0 \%$ or 0 students in pre cycle to $80 \%$ or 32 students in cycle $1,95 \%$ or 38 students in cycle 2 and cycle 3.The score of questioning activity from students in written improves from $0 \%$ or 0 students in pre cycle to $37,5 \%$ or 15 students in cycle $1,45 \%$ or 18 students in cycle 2 and $52,5 \%$ or 21 student in cycle 3 . Data improvement of each aspect of students' questioning activity from pre cycle until cycle 3 has reached the research target $(\geq 50 \%)$. Based on the result, it can be concluded that guided inquiry model improves questioning activity in learning material "Animalia" of class X Science 6 of SMA Negeri 1 Karanganyar in 2015/2016 academic year.
\end{abstract}

Keywords: questioning activity, guided inquiry

\section{PENDAHULUAN}

Penerapan Kurikulum 2013 menuntut siswa untuk berperan secara aktif selama proses pembelajaran. Peran aktif siswa menunjukkan keterlibatan siswa dalam pembelajaran yang interaktif. Pembelajaran interaktif merupakan pembelajaran yang berpusat pada siswa dengan mendorong siswa aktif bertanya melalui interaksi guru dan siswa dalam proses pembelajaran.

Keaktifan bertanya siswa perlu dikembangkan karena partisipasi siswa dalam mengajukan pertanyaan selama proses pembelajaran memiliki berbagai peranan penting. Bagi siswa pertanyaan yang diajukan dapat mengarahkan siswa dalam membangun pengetahuan, mengaktifkan diskusi dalam meningkatkan kualitas interaksi pembelajaran di kelas, membantu siswa mengevaluasi pemahaman, serta meningkatkan minat belajar dengan membangkitkan rasa ingin tahu siswa. Sedangkan bagi guru, pertanyaan yang diajukan siswa dapat membantu guru mendiagnosa pemahaman siswa dan memantau pemikiran mereka sehingga bertindak sebagai alat bantu dalam penilaian formatif sebagai bahan masukan pembelajaran selanjutnya, mengevaluasi keterampilan berpikir tingkat tinggi siswa, mendorong penyelidikan lebih lanjut pada materi pembelajaran, dan membantu merefleksi secara kritis kegiatan pembelajaran (Chin \& Osborne, 2008).

Proses pembelajaran yang berlangsung saat observasi yang dilakukan di kelas X MIA 6 SMA Negeri 1 Karanganyar pada hari Selasa tanggal 19 Januari 2016 menunjukkan bahwa keaktifan bertanya siswa dalam kegiatan pembelajaran masih kurang sehingga perlu ditingkatkan. Selama observasi, siswa masih pasif untuk berpartisipasi dalam proses pembelajaran, karena kegiatan siswa hanya mendengarkan dan mencatat penjelasan yang disampaikan oleh guru. Siswa yang bertanya sebesar $7,5 \%$ atau 3 siswa dan siswa yang berpendapat sebesar 35\% atau 14 siswa. Selama pembelajaran berlangsung, guru menerapkan metode ceramah dengan bantuan media powerpoint. Interaksi yang berlangsung selama proses pembelajaran masih satu arah yaitu guru kepada siswa dan guru terlihat lebih dominan selama pembelajaran. Hal tersebut dibuktikan dengan aktivitas guru yang menjelaskan semua materi yang dipelajari dan bertanya kepada siswa sebanyak 18 pertanyaan.

Observasi lanjutan dilaksanakan pada hari Selasa, 26 Januari 2016 dengan topik Plantae pokok 
bahasan Bryophyta menunjukkan hasil bahwa guru masih menerapkan metode ceramah dan menjelaskan semua materi secara langsung kepada siswa. Saat observasi, menunjukkan bahwa guru masih terlihat lebih dominan berpartisipasi dibandingkan dengan siswa dan interaksi bertanya siswa kepada guru ataupun interaksi bertanya siswa dengan siswa lainnya masih kurang. Guru bertanya sebanyak 19 pertanyaan kepada siswa dan siswa menjawab secara serentak. Siswa yang bertanya kepada guru sebanyak 3 siswa atau 7,5\% dengan total 3 pertanyaan dan tidak ada siswa yang bertanya kepada teman ataupun secara tertulis. Siswa yang berpendapat menjawab pertanyaan guru secara serentak sebesar 16 siswa atau $40 \%$. Selama pembelajaran berlangsung sebanyak $92,5 \%$ atau 37 siswa di kelas X MIA 6 menunjukkan pasif bertanya, kegiatan yang dilakukan oleh siswa adalah mendengarkan dan mencatat materi yang disampaikan oleh guru.

Hasil observasi lanjutan terkait kurangnya keaktifan bertanya siswa di kelas, didukung dengan hasil wawancara kepada guru dan siswa. Guru menyatakan bahwa siswa kelas X MIA 6 setiap pembelajaran biologi jarang yang aktif bertanya. Siswa mengungkapkan bahwa siswa pasif bertanya secara langsung di kelas karena malu apabila pertanyaan yang diajukan tidak masuk akal sebesar 32,5\%, siswa tidak suka mengungkapkan pertanyaan di depan kelas sebesar $52,5 \%$, dan siswa bingung terkait hal yang ingin ditanyakan sebesar $25 \%$. Siswa yang tidak bertanya secara tertulis beralasan bahwa siswa bingung terkait hal yang ingin ditanyakan secara tertulis karena semua materi sudah disampaikan oleh guru selama pembelajaran sebesar $80 \%$ dan siswa lainnya menyatakan bahwa siswa memang tidak berminat untuk bertanya secara tertulis sebesar $20 \%$.

Materi Animalia sesuai dengan silabus Kurikulum 2013 merupakan materi pada Kompetensi Dasar (KD) 3.8 menerapkan prinsip klasifikasi untuk menggolongkan hewan ke dalam filum berdasarkan pengamatan anatomi, dan morfologi serta mengaitkan peranannya dalam kehidupan. Berbagai jenis hewan dalam klasifikasi Kingdom Animalia dan peranannya mudah dijumpai oleh siswa di kehidupan sehari-hari. Desain pembelajaran untuk penyampaian materi Kingdom Animalia diperlukan proses kegiatan belajar yang memfasilitasi siswa untuk mengembangkan pengetahuan melalui penyelidikan ilmiah dengan obyek hewan yang disekitar siswa, sehingga dapat merangsang rasa ingin tahu siswa melalui bertanya dan menyebabkan pembelajaran yang aktif berpusat pada siswa.

Keaktifan bertanya siswa X MIA 6 di SMA Negeri 1 Karanganyar dari hasil observasi yang telah dilakukan khususnya pada mata pelajaran Biologi perlu ditingkatkan. Akar masalah kurangnya keaktifan bertanya siswa kelas X MIA 6 di sekolah SMA Negeri 1 Karanganyar adalah kegiatan proses pembelajaran minim untuk memunculkan rasa ingin tahu siswa terhadap materi yang sedang dipelajari sehingga mengakibatkan siswa kurang berminat untuk bertanya dan proses pembelajaran biologi masih didominasi oleh penjelasan materi dari guru sehingga membuat siswa pasif bertanya selama proses pembelajaran. Selama pembelajaran, guru sering mendominasi kelas dengan mengajukan banyak pertanyaan dibandingkan dengan siswa (Almeida, 2010).

Solusi untuk meningkatkan keaktifan bertanya siswa dengan model pembelajaran inkuiri terbimbing sebagai upaya meningkatkan keaktifan bertanya siswa pada materi Animalia. Pembelajaran inkuiri merupakan bentuk dari pendekatan pembelajaran yang berorientasi kepada siswa, sehingga siswa memiliki peran yang dominan dalam proses pembelajaran. Model pembelajaran inkuiri dapat memusatkan siswa untuk mengembangkan pertanyaan, ide, dan kegiatan penyelidikan melalui pengalaman belajar. Berdasarkan uraian dari latar belakang diatas maka peneliti mengambil judul "Peningkatan Keaktifan Bertanya Melalui Inkuiri Terbimbing Siswa Kelas X MIA 6 SMA Negeri 1 Karanganyar Tahun Pelajaran 2015/2016".

\section{METODE PENELITIAN}

Penelitian dilaksanakan di kelas X MIA 6 SMA Negeri 1 Karanganyar pada semester genap Tahun Pelajaran 2015/2016. SMA Negeri 1 Karanganyar beralamat di Jalan A.W. Monginsidi 03 Kabupaten Karanganyar.

Data penelitian keaktifan bertanya siswa yang diukur tediri dari 3 aspek yaitu keaktifan bertanya kepada guru, keaktifan bertanya kepada teman, dan keaktifan secara tertulis. Data pendukung berupa hasil belajar psikomotorik, hasil belajar afektif, dan hasil belajar kognitif. Sumber data dalam penelitian ini meliputi: (1) guru mata pelajaran Biologi kelas X MIA 6 SMA Negeri 1 Karanganyar, (2) siswa kelas X MIA 6 SMA Negeri 1 Karanganyar, (3) dokumen hasil perangkat instrumen pembelajaran dan instrumen penelitian meliputi RPP, Lembar Kerja Siswa, lembar penilaian, dan lembar observasi.

Teknik yang digunakan untuk memperoleh data penelitian yang valid dari kegiatan penelitian adalah dengan teknik triangulasi. Teknik triangulasi yang digunakan meliputi observasi, wawancara, dan dokumentasi .

Indikator keberhasilan penelitian adalah tercapainya peningkatan siswa yang aktif bertanya setiap aspek keaktifan bertanya sebesar $\geq 50 \%$ dari total siswa dan peningkatan jumlah skor pertanyaan yang diajukan oleh siswa dari baseline.

Prosedur penelitian yang dilakukan mengikuti model siklus menurut Kemmis dan Mc. Taggart (2005) yang dilakukan secara berulang-ulang atau bersiklus dan berkelanjutan. Setiap siklusnya terdiri dari empat tahap yaitu tahap perencanaan, tindakan, observasi, dan refleksi. 


\section{HASIL DAN PEMBAHASAN}

Berdasarkan hasil penelitian penerapan model inkuiri terbimbing dapat meningkatkan keaktifan bertanya dalam materi Animalia siswa kelas X MIA 6 SMA Negeri 1 Karanganyar Tahun Pelajaran 2015/2016.

Peningkatan keaktifan bertanya siswa ditunjukkan dengan meningkatnya capaian skor aspek keaktifan bertanya siswa kepada guru, kepada teman, dan secara tertulis dari tahap pratindakan, tahap siklus 1, tahap siklus 2, dan tahap siklus 3 .

Peningkatan hasil observasi capaian skor setiap indikator keaktifan bertanya siswa kepada guru pada setiap siklusya disajikan pada Gambar 1.

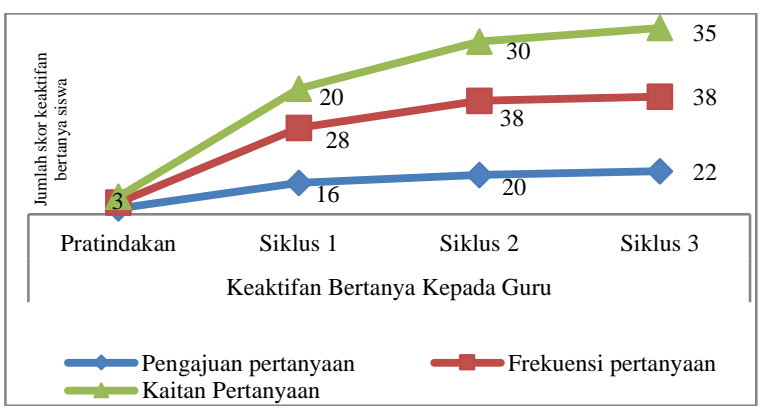

Gambar 1. Kenaikan Skor Aspek Keaktifan Bertanya Siswa Kepada Guru Tahap Pratindakan, Tahap Siklus 1, Tahap Siklus 2, dan Tahap Siklus 3

Berdasarkan hasil analisis yang disajikan dalam Gambar 1 menunjukkan setiap indikator dari aspek keaktifan bertanya siswa kepada guru mengalami peningkatan pada seluruh siklus. Keaktifan bertanya siswa kepada guru terkait pengajuan pertanyaan pada tahap siklus 1 yaitu 16 siswa atau $40 \%$ mengalami peningkatan dari hasil pratindakan, kemudian meningkat ke siklus 2 yaitu 20 siswa atau 50\% dan tahap siklus 3 menjadi 22 siswa atau 55\%. Skor frekuensi pertanyaan dan kaitan pertanyaan keaktifan bertanya kepada guru setiap siklusnya menunjukkan mengalami peningkatan dari baseline. Pada tahap siklus 1 aspek keaktifan bertanya kepada guru belum mencapai target dikarenakan belum optimalnya tindakan pada setiap tahap inkuiri terbimbing dan kondisi siswa yang masih memerlukan penyesuaian untuk melaksanakan secara disiplin dan sistematis pada setiap kegiatan pada tahap inkuiri terbimbing. Ketercapaian target aspek keaktifan bertanya siswa kepada guru terjadi pada tahap siklus 2 dan tahap siklus 3, karena pada tahap siklus 2 siswa mulai terbiasa berinteraksi mengungkapkan rasa ingin tahunya kepada guru dan pada tahap siklus 3 penerapan inkuiri terbimbing telah terlaksana dengan optimal.

Peningkatan hasil observasi capaian skor setiap indikator keaktifan bertanya siswa kepada teman pada setiap siklusnya disajikan pada Gambar 2 .

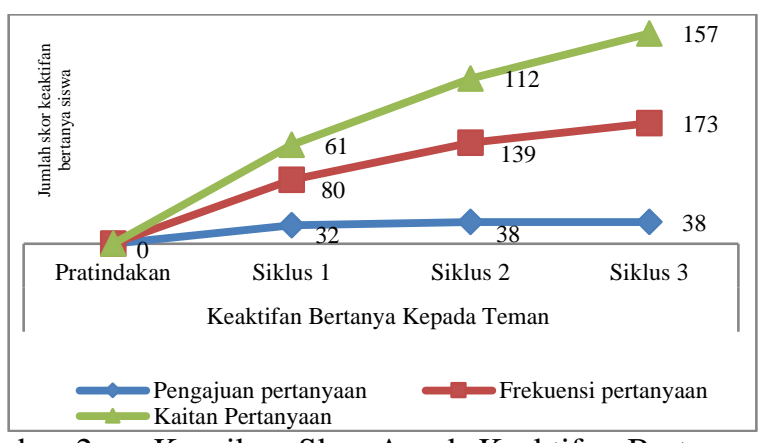

Gambar 2. Kenaikan Skor Aspek Keaktifan Bertanya Siswa Kepada Teman Tahap Pratindakan, Tahap Siklus 1, Tahap Siklus 2, dan Tahap Siklus 3

Berdasarkan hasil analisis yang disajikan dalam Gambar 2 menunjukkan setiap indikator dari aspek keaktifan bertanya siswa kepada teman mengalami peningkatan pada seluruh siklus. Keaktifan bertanya siswa kepada teman terkait pengajuan pertanyaan pada tahap siklus 1 yaitu 32 siswa atau $80 \%$ mengalami peningkatan dari hasil pratindakan, kemudian meningkat ke tahap siklus 2 yaitu 38 siswa atau 95\% dan tahap siklus 3 tidak mengalami perubahan yaitu 38 siswa atau 95\%. Skor frekuensi pertanyaan dan kaitan pertanyaan keaktifan bertanya kepada teman setiap siklusnya menunjukkan mengalami peningkatan dari baseline. Ketercapaian target aspek keaktifan bertanya siswa kepada teman terjadi pada tahap siklus 1, tahap siklus 2 dan tahap siklus 3 karena dengan penerapan inkuiri terbimbing siswa terfasilitasi untuk berinteraksi dan berdiskusi dengan temannya sehingga menyebabkan siswa aktif bertanya kepada teman.

Peningkatan hasil observasi capaian skor setiap indikator keaktifan bertanya siswa secara tertulis pada setiap siklusnya disajikan pada Gambar 3.

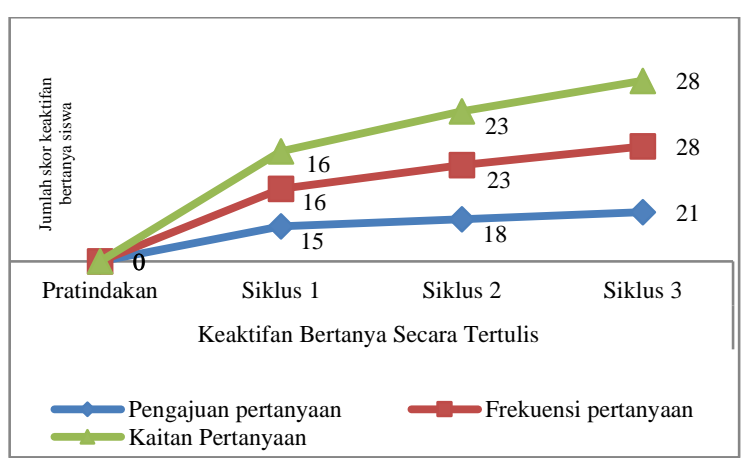

Gambar 3. Kenaikan Skor Aspek Keaktifan Bertanya Siswa Secara Tertulis Tahap Pratindakan, Tahap Siklus 1, Tahap Siklus 2, dan Tahap Siklus 3

Berdasarkan hasil analisis yang disajikan dalam Gambar 3 menunjukkan setiap indikator dari aspek keaktifan bertanya siswa secara tertulis mengalami peningkatan pada seluruh siklus. Keaktifan bertanya siswa secara tertulis terkait pengajuan pertanyaan pada tahap siklus 1 yaitu 15 siswa atau $37,5 \%$ mengalami peningkatan dari hasil pratindakan, kemudian meningkat 
ke tahap siklus 2 yaitu 18 siswa atau $45 \%$ dan siklus 3 menjadi 21 siswa atau 52,5\%. Skor frekuensi pertanyaan dan kaitan pertanyaan keaktifan bertanya secara tertulis setiap siklusnya menunjukkan mengalami peningkatan dari baseline. Pada tahap siklus 1 aspek keaktifan bertanya siswa secara tertulis belum mencapai target dikarenakan belum optimalnya tindakan pada setiap tahap inkuiri terbimbing, dan kondisi siswa yang masih memerlukan penyesuaian untuk melaksanakan secara disiplin dan sistematis pada setiap kegiatan pada tahap inkuiri terbimbing, kemudian pada tahap siklus 2 belum tercapainya target disebabkan kondisi siswa yang masih kurang fokus memperhatikan tahap kegiatan yang dilaksanakan karena sibuk dengan kepentingan masingmasing siswa dalam kelompoknya. Ketercapaian target aspek keaktifan bertanya siswa secara tertulis terjadi pada tahap siklus 3, karena pada tahap siklus 3 penerapan semua tahap pada inkuiri terbimbing telah terlaksana secara optimal.

Peningkatan keaktifan bertanya siswa pada setiap siklusnya terjadi karena adanya penerapan model inkuiri terbimbing. Sintaks dari model inkuiri terbimbing mampu memfasilitasi peserta didik untuk mengembangkan kemampuan penyelidikan dalam diskusi dan mampu mengakomodasi siswa untuk mengajukan pertanyaan.

Kegiatan bertanya siswa pada tahapan observe atau observasi dan mempelajari materi merupakan tahapan pengamatan oleh siswa di tahap siklus 1, tahap siklus 2, dan tahap siklus 3 menyebabkan munculnya rasa ingin tahu siswa terhadap pengamatan fenomena yang meliputi berbagai jenis hewan Invertebrata yang disajikan oleh guru. Menurut Bell, et al. (2010) pengamatan yang dilakukan terhadap fenomena mampu membangkitkan minat dan rasa ingin tahu siswa. Tahap formulate inquiry question atau pengajuan pertanyaan merupakan tahapan siswa menyusun pertanyaan di tahap siklus 1, tahap siklus 2, dan tahap siklus 3 telah mampu mengembangkan keaktifan bertanya siswa karena siswa dituntut untuk merumuskan berbagai pertanyaan dari fenomena yang disajikan. Tahap pengajuan pertanyaan akan mengeksplorasi kemampuan siswa dalam merumuskan pertanyaan yang baik dan relevan sehingga dapat diselidiki jawabannya melalui kegiatan ilmiah (Bell, et al., 2010). Tahap design and conduct investigation di tahap siklus 1 , tahap siklus 2, dan tahap siklus 3 telah mampu mengembangkan keaktifan bertanya untuk menyesuaikan prosedur penyelidikan yang disusun dengan permasalahan yang akan ditemukan solusinya. Tahap Analyze data atau analisis data pada tahap siklus 1, tahap siklus 2, dan tahap siklus 3 merupakan tahapan menganalisis data hasil penyelidikan melalui kegiatan diskusi kelompok. Van Zee, E.H., et al. (2001) menyatakan bahwa kegiatan diskusi kelompok kecil pada siswa akan mengembangkan keaktifan bertanya karena siswa saling bekerja sama antara anggota kelompok untuk saling bertukar pikiran, selain itu siswa merasa terfasilitasi dengan nyaman dalam kelompok untuk bertanya. Tahap arguing atau argumentasi pada tahap siklus 1, tahap siklus 2, dan tahap siklus 3 merupakan tahapan mengkomunikasikan hasil penyelidikan kelompok melalui presentasi setiap kelompok. Pemahaman siswa terhadap materi yang sedang dipelajari dapat diklarifikasi melalui tahapan komunikasi (Chang, et al., 2010).

Peningkatan keaktifan bertanya siswa dari tahap siklus 1, tahap siklus 2, dan tahap siklus 3 berdampak pada kemampuan siswa dalam menjawab pertanyaan soal kognitif di setiap akhir siklusnya Hasil dari penilaian evaluasi kognitif siswa dari tahap siklus 1 sampai tahap siklus 3 menunjukkan adanya peningkatan hasil kognitif siswa kelas X MIA 6 SMA Negeri 1 Karanganyar. Pada tahap siklus 1 rata-rata penilaian kogitif siswa adalah 81,4 kemudian pada tahap siklus 2 mengalami peningkatan menjadi 86,05 dan pada tahap siklus 3 menjadi 88,85. Menurut teori belajar Piaget seseorang akan mengasimilasi dan mengakomodasi pengetahuan yang ada disekitarnya (Dahar, 2006). Pada setiap tahapan inkuiri terbimbing yang dilaksanakan dalam penelitian telah mengarahkan siswa untuk melakukan proses asimiliasi, akomodasi, dan ekulibrasi. Setiap siswa yang melakukan proses asimilasi, akomodasi, dan ekulibrasi akan menyebabkan munculnya konflik kognitif dalam pikirannya, sehingga akan mendorong siswa untuk aktif bertanya sampai siswa mendapatkan konsep baru yang diinginkan. Siswa yang mendapatkan konsep sendiri akan bertahan lebih lama dan lebih bermakna sehingga dapat meningkatkan retensi siswa. Meningkatnya retensi siswa terhadap materi yang telah dipelajari berdampak pada kemampuan siswa dalam menjawab soal kognitif siswa. Menurut Agustina, et al. (2015) keaktifan bertanya siswa akan mempengaruhi hasil belajar siswa karena siswa yang paham terhadap materi akan memiliki keberanian dan rasa percaya diri untuk bertanya, sehingga akan meningkatkan pemahaman terhadap materi yang dipelajari yang akhirnya berdampak baik terhadap hasil belajar siswa.

Keaktifan bertanya siswa kepada teman dari tahap siklus 1 sampai dengan tahap siklus 3 mendapatkan skor yang tertinggi dibandingkan keaktifan siswa bertanya kepada guru dan secara tertulis karena adanya kegiatan diskusi kelompok siswa. Menurut Hobson dan Bohon (2011) kegiatan diskusi kelompok kecil pada siswa saat pembelajaran, sangat efektif untuk melibatkan siswa aktif bertanya dengan temannya daripada kepada guru karena jika bertanya kepada teman siswa merasa lebih nyaman untuk menyanggah dibandingkan kepada guru. Keaktifan bertanya siswa secara tertulis mendapatkan skor terendah dibandingkan keaktifan bertanya kepada guru dan teman tetapi semua pertanyaan yang diajukan secara tertulis memiliki kaitan pertanyaan yang dipelajari siswa. Hal tersebut karena siswa telah mengomptimalkan keaktifan bertanya secara lisan di kelas sehingga hanya sebagian siswa yang masih memiliki pertanyaan untuk diajukan secara tertulis. Pertanyaan yang diajukan siswa secara tertulis lebih 
terfokus pada ketidakpemahaman terhadap materi sehingga semua pertanyaan berkaitan terhadap pokok bahasan yang telah dipelajari. Menurut Kelling, et al. (2009) siswa yang bertanya melalui tulisan dapat membantu siswa dalam memusatkan perhatian dan pemahaman terhadap materi yang dipelajari.

Hasil wawancara dengan siswa kelas X MIA 6 SMA Negeri 1 Karanganyar di setiap siklusnya diperoleh simpulan alasan siswa untuk aktif ataupun tidak aktif bertanya kepada guru, teman, dan secara tertulis. Siswa yang bertanya kepada guru memiliki alasan diantaranya siswa lebih mempercayai guru lebih bisa menjawab berbagai kesulitan yang dialami oleh siswa, guru sedang berada di dekat siswa ketika siswa mengalami kesulitan. Siswa yang bertanya kepada teman memiliki alasan diantaranya siswa lebih nyaman, leluasa, tidak kaku apabila bertanya kepada teman dibandingkan guru, teman sedang mempresentasikan materi yang ingin ditanyakan, dan siswa sedang berdiskusi dengan teman sekelompok sehingga ada interaksi untuk bertanya. Siswa memilih aktif bertanya secara tertulis karena tidak berkesempatan bertanya saat pembelajaran langsung di kelas karena kehabisan waktu saat sesi tanya jawab dan ada siswa yang beralasan tidak suka bertanya secara langsung di kelas sehingga lebih memilih untuk menuliskan pertanyaannya.

Siswa yang tidak aktif bertanya kepada guru, teman, dan tertulis beralasan bahwa mereka sudah paham terkait materi yang sudah dipelajari sehingga tidak ada yang ingin ditanyakan, pertanyaan yang ingin diajukan sudah disampaikan oleh teman lain, siswa takut pertanyaan yang diajukan dianggap tidak masuk akal, siswa tidak suka mengungkapkan pertanyaan di depan kelas, siswa bingung hal yang ingin ditanyakan dan sebagian dari siswa ada yang lebih memilih mencari jawaban sendiri dibandingkan bertanya di kelas.

Hasil simpulan wawancara dengan guru Biologi kelas X MIA 6 SMA Negeri 1 Karanganyar di setiap siklusnya diketahui bahwa selama pembelajaran tahap siklus 1 , tahap siklus 2 , dan tahap siklus 3 siswa terlihat lebih antusias untuk mengikuti kegiatan pembelajaran dan lebih aktif berpartisipasi bertanya dikarenakan adanya kegiatan siswa bisa mengamati langsung berbagai Invertebrata yang sedang dipelajari. Guru berpendapat bahwa pertanyaan yang diajukan siswa beragam mulai dari klasifikasi, karakteristik, dan peran dari Invertebrata yang dipelajari.

\section{SIMPULAN}

Berdasarkan hasil penelitian dapat disimpulkan bahwa melalui penerapan model inkuiri terbimbing ada peningkatan keaktifan bertanya dalam materi Animalia siswa kelas X MIA 6 SMA Negeri 1 Karanganyar Tahun Pelajaran 2015/2016.

\section{DAFTAR PUSTAKA}

Agustina, P., Lisdiana, \& Marianti, A. (2015). Problem posing card (PPC) : meningkatkan keterampilan bertanya dan hasil belajar siswa.Unnes Journal of Biology Education, 282-289.

Almeida, P. A. (2010). Classroom questioning: teachers' perceptions and practices. University of Aveiro, Portugal: Procedia Social and Behavioral Sciences 2.

Bell, et.al. (2010). Collaborative inquiry learning : models, tools, and challenges. International Journal of Science Education, 32, 349-377.

Chang, H., et al. (2010). The development of a competence scale for learning science: inquiry and communication. International Journal of Science and Mathematics Education, 9, 1213-1233

Chin, C., \& Osborne, J. (2008). Students' questions: a potential resource for teaching and learning. Studies in Science Education, 44(1), 1-39.

Dahar, Ratna Wilis. (2006). Teori-Teori Belajar \& Pembelajaran. Jakarta: Erlangga.

Hobson, E., \& Bohon, L. (2011). The effects of culture on student questioning in the science classroom. Journal of Cross Disciplinary Perspectives in Education, 4, 41-50.

Kelling, E., Polacek, K., \& Ingram, E. (2009). A statistical analysis of student questions in a cell. CBE-Life Sciences Education, 131-139.

Kemmis, S., \& McTaggart, R. (2005). Participatory Action Research: Communicative action and the public sphere. Dalam Denzin, N. K., \& Lincoln, Y. S (Ed). Strategies of Qualitative Inquiry, 271-330. Thousand Oaks, CA: Sage.

Van Zee, E.H., et al. (2001). Student and teacher questioning during conversations about science. Journal of Research in Science Teaching,38, 159-190. 